ОРИГИНАЛНИ НАУЧНИ ЧЛАНЦИ

ОРИГИНАЛЬНЫЕ НАУЧНЫЕ СТАТЬИ

ORIGINAL SCIENTIFIC PAPERS

\title{
SINGLE SHOT HIT PROBABILITY ESTIMATION AS A RESULT OF THE NUMERICAL SOLUTION OF DOUBLE INTEGRALS USING MATHCAD
}

\author{
Vadim L. Khaikov \\ independent researcher, Krasnodar, Russian Federation, \\ e-mail: wadimhaikow@inbox.ru, \\ ORCID iD: (1)http://orcid.org/0000-0003-1433-3562
}

DOI: 10.5937/vojtehg66-17433; https://doi.org/10.5937/vojtehg66-17433

FIELD: Applied Mathematics

ARTICLE TYPE: Original Scientific Paper

ARTICLE LANGUAGE: English

\section{Abstract:}

A geometric interpretation of single shot hit probability (Phit) is a volume of 3D space enclosed above by the surface $f(y, z)$ described the bivariate normal distribution and bounded from below by the YOZ plane with the target's contour (T-region). The Phit is proposed to estimate by a method based on the numerical integration of the double integral. Its integrand is the $2 D$ normal distribution of $Y, Z$ system of random variables. The dispersion characteristics and coordinates of the dispersion center are known in advance. Limits of first and second integrals are described by the analytic functions, which characterize the geometric shape of the $T$ region. Implementation of the offered method: the selected shooting target is partitioned into $N$ geometric subregions; for each of it, analytic formula(s) for the subregion's boundaries is determined and each double integral is defined. The Phit estimations are produced using a numerical integration in the computer software Mathcad. The results of the calculus of all Phits (for subregions) are added up (or subtracted) depending on the geometric relationships between them. The schema for numerically Phit solving makes it possible to calculate a likelihood for targets with arbitrary geometric shapes and not just rectangular-shaped silhouettes. For illustrating the operability of the proposed method, the Phit for two kinds of head-type shooting targets had been evaluated. The developed method had been compared with the already existing works.

Key words: hit probability, numerical solution, shooting target, double integrals, shot dispersion, Mathcad. 


\section{Introduction}

Computational methods for single shot hit probability estimation by shooting to targets were proposed in works (Rodney, 2012), (Svateev, 2014) and (Khaikov \& Popovnin, 2018). The problem is solved by using a special tabular function or the mathematical function "erf», which is also known as the Gauss error integral (Zwillinger \& Kokoska, 2000).

If the target contour is associated with a geometrical $T$-region and if it is replaced by a group of rectangles so that the area of the original $T$ region and the area of a new rectangle group are equal and the sides of all rectangles are parallel to the main dispersion axes, then, in this case, the hit probability of the $T$-region is equal to the sum of hit probabilities each of rectangles obtains after the "replacement» procedure (Abezgauz et al, 1970, pp.162-163), (Vodorezov, 2017, p.332).

The subjective side of the "replacement» method is an uncertainty in the methodology of its conduct, so it is often said that the breakdown of the $T$-region into rectangles is carried out «by eye». For example, in (Rodney, 2012, p.4), where the hit probability for RPG grenades fired at a helicopter is estimated, there is no explanation why the 2D representation of the Boeing $\mathrm{CH}-47$ consists of six rectangles. Quite often in practice, there is a situation where it is necessary to assess hit probabilities for targets with complex contours.

The aim of the article ${ }^{1}$ is in the first place to overcome the deficiency of the «replacement» method; and, in the second place, to develop a more accurate path for estimating the single shot hit probability in a target with an arbitrary contour. The main tool for solving this problem will be the double integral ${ }^{2}$ and its geometric and physical interpretations.

\section{The hit probability estimation process}

Double integrals for hit probability determination. The calculation of the probability that a bullet (projectile) impacts a target is reduced to computing the hit probability into some region $T$ of a complex geometric shape. Let the random point $(Z, Y)$ in the plane be subject to the normal

\footnotetext{
${ }^{1}$ This article continues the cycle of works devoted to the use of the MATHCAD computer software for ballistic tasks of small arms and tubed artillery armament.

2 It is known that, thanks to the use of the double integral, the area of a geometric figure and a mass of a flat plate with variable density can be calculated as well as the static moment and the center of gravity of a plate and its moment of inertia.
} 
distribution. In this case, the axes of dispersion are parallel to the coordinate axes.

If the $T$ region (letter «T» means a target) is a plane figure, and the probability of hit of the random variables $Z$ and $Y$ is determined by the normal (Laplace-Gauss) distribution $f(z, y)$, then the target hit probability is defined by the formula (1) (Venttsel', 2006, p.196)

$$
P[(Z, Y) \subset T]=\iint_{T} f(z, y) d z d y
$$

where $T$ - the region of integration in the zy-plane; $z, y-$ the Cartesian coordinates; $\sigma_{z}, \sigma_{y}$ - the standard deviation of the continuous random variables $Z, Y ; m_{z}, m_{y}$ - coordinates of the center of dispersion (the mean of $Z$ and $Y) ; \quad f(z, y)$ - the integrand and the bivariate normal distribution law:

$$
f(z, y)=\frac{1}{2 \pi \sigma_{z} \sigma_{y}} \exp \left(-\left[\frac{\left(z-m_{z}\right)^{2}}{2 \sigma_{z}^{2}}+\frac{\left(y-m_{y}\right)^{2}}{2 \sigma_{y}^{2}}\right]\right)
$$

The correlation coefficient $(r)$ between $Z$ and $Y$ is 0 (Venttsel', 2006, p.191). In (1), the axes of dispersion are parallel to the coordinate axes.

If the contour of a planar $T$ region is placed in the Cartesian coordinates and bound above and below by functions $y_{2}=\varphi_{2}(z)$, $y_{1}=\varphi_{1}(z)$, and to the left and right by lines $z=a, z=b$ (Fig. 1a), if each point inside $T$ is described by equation $f(z, y)$ with parameters $m_{z}, m_{y}$ and $\sigma_{z}, \sigma_{y}$ (Fig. 1b), then the hit probability in $T$ is determined by the double integral (Piskunov, 1985):

$$
\iint_{T} f(z, y) d z d y=\int_{a}^{b} \int_{\varphi_{1}(z)}^{\varphi_{2}(z)} f(z, y) d z d y=\int_{a}^{b} d z \int_{\varphi_{1}(z)}^{\varphi_{2}(z)} f(z, y) d y .
$$




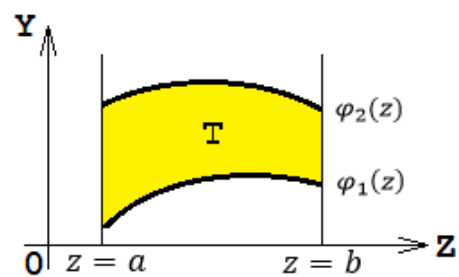

a)

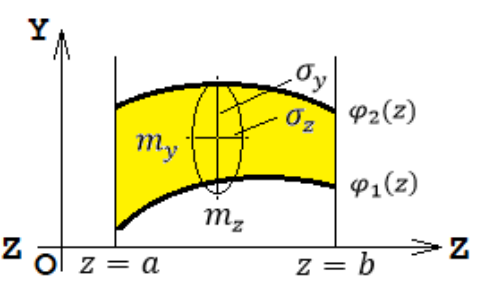

b)

Figure $1-2 D$ geometric interpretation of the double integrals (a) and a target hit probability (b)

Puс. 1 - Геометрическая интерпретация двойного интеграла (а) и вероятности попадания (b) в плоские мишени

Слика 1 - Дводимензионално представљање двоструких интеграла (а) и вероватноће поготка циља (б)

The limits of integration for $\varphi_{1}(z)$ and $\varphi_{2}(z)$ correspond with the $d y$. Similarly, the limits of integration $a$ and $b$ correspond with the $d z$. In this way

$$
P[(Z, Y) \subset T]=\frac{1}{2 \pi \sigma_{z} \sigma_{y}} \int_{a}^{b} \int_{\varphi_{1}(z)}^{\varphi_{2}(z)} \exp \left(-\left[\frac{\left(z-m_{z}\right)^{2}}{2 \sigma_{z}^{2}}+\frac{\left(y-m_{y}\right)^{2}}{2 \sigma_{y}^{2}}\right]\right) d z d y .
$$

The geometric interpretation of target hit probability is the volume under a surface $f(y, z)$ ( $A^{\prime} B^{\prime} C^{\prime} D^{\prime} E^{\prime} F^{\prime}$ region), which is a part of the bivariate normal distribution, limited from below the YOZ-plane the part of which the target contour borders ( $A B C D E F$ is the $T$-region).

A three-dimensional geometric interpretation of hit probability is shown in Figure $2 a$. Figure $2 b$ shows that the volume of the 3D-figure $\left(A^{\prime} B^{\prime} C^{\prime} D^{\prime} E^{\prime} F^{\prime} F A B C D E\right)$ is equal to the hit probability in a target, the shape of which is equal to the base of the 3D-figure $(A B C D E F$ polygon $=T$ region).

In the case that the calculation of the double integral is performed with respect to the OY axis, it is necessary to consider the following calculation scheme (Fig. 3). If the region $T$ is correct in the direction of the OZ axis, then (Piskunov, 1985)

$$
\iint_{T} f(z, y) d z d y=\int_{c}^{d}\left(\int_{f_{1}(y)}^{f_{2}(y)} f(z, y) d z\right) d y,
$$


where $z=f_{1}(y), z=f_{2}(y)$ are the equations of the curves that bound the region $T$ to the left and to the right, respectively. The segment $[c ; d]$ is the projection of the region $T$ onto the axis $O Y$.

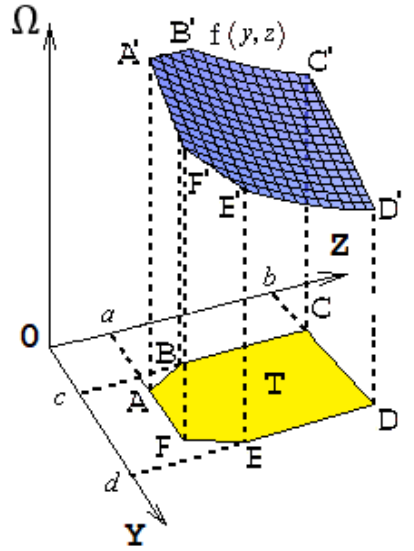

a)

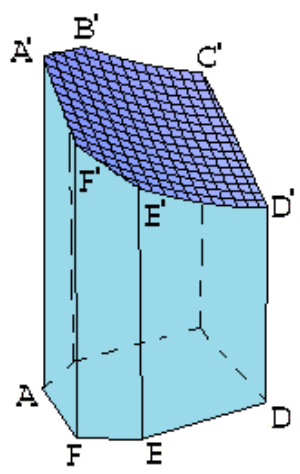

b)

Figure $2-3 D$ geometric interpretation of hit probability

Puc. 2 - Пространственная геометрическая интерпретация вероятности попадания в цель

Слика 2 - Тродимензионално представљање вероватноће поготка

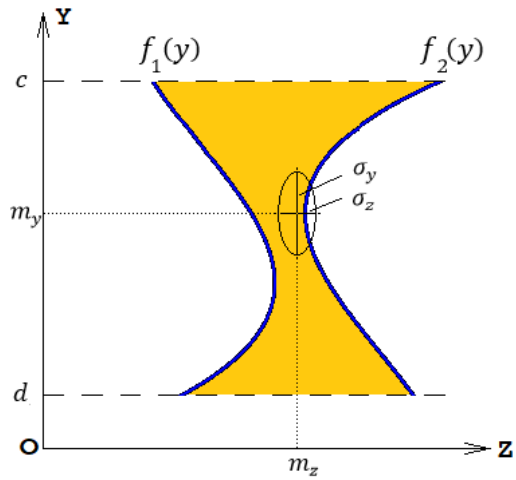

Figure 3 - The scheme for calculating a double integral with respect to the OY axis

Puc. 3 - Схема вычисления двойного интеграла относительно оси ОY Слика 3 - Шема за израчунавање двоструког интеграла у односу на OY осу

A general region $T$ has the property of «correctness» in the direction of the axis $O Y(O Z)$ if any line passing through any interior point of this 
region $(T)$ is parallel to the axis $O Y(O Z)$ and intersects each of the two boundaries of the region at only one point, and each of the intersected boundaries is specified by one equation.

In addition, the following conditions must be fulfilled (see Fig. 1-3):

for $O Y$ axis (Fig. 3) $\quad T=\left\{(z, y) \mid c \leq y \leq d, f_{1}(y) \leq z \leq f_{2}(y)\right\}$

for $O Z$ axis (Fig. 1) $\quad T=\left\{(z, y) \mid a \leq y \leq b, \varphi_{1}(z) \leq y \leq \varphi_{2}(z)\right\}$.

The triangle shows the point of the intersection of a line with the axis OY $(O Z)$. The squares are the points of the intersection of a line with the functions $f_{1}(y), f_{2}(y)$ or $\varphi_{1}(z), \varphi_{2}(z)$.

A hit probability estimation algorithm. The basic algorithm of a hit probability numerical assessment consists of the following procedures:

1) the beginning;

2) to define the Cartesian coordinates (origin point, $O Z$ axis, $O Y$ axis);

3 ) to construct the contour of the shooting target ( $T$ region);

4) to find the coordinates of the target contour;

5) to find an analytical expression of the boundaries of the target

$\boldsymbol{F}_{1}, \boldsymbol{F}_{2}$ or $\boldsymbol{\Phi}_{1}, \boldsymbol{\Phi}_{2}$

6) to describe the rectangle near the target (main rectangle);

7) to determine the location of the point of impact (POI) $m_{z}, m_{y}$;

8) to determine the characteristics of the dispersion ellipse $\sigma_{z}, \sigma_{y}$;

9 ) to calculate the hit probability in the basic rectangle $\left(P_{\text {hit basic }}\right)$;

10 ) to determine the number of subregions $N$ (for subtraction from the basic rectangle);

for each subregion $i(j \leq N)$ :

11) to determine the limits for numerical integration;

12) to solve numerically the inner integral;

13) to solve numerically the outer integral and to get the hit probability of a subregion;

14) to sum the hit probabilities of all subregions to get the hit probability of subfigures $\left(P_{\text {hit subreg }}=P_{\text {hit reg } 1}+P_{\text {hit reg i }}+P_{\text {hit reg } N}\right)$;

15) $P_{\text {hit }}=P_{\text {hit_basic }}-P_{\text {hit_subreg; }}$

16) the end.

If the shooting target is a figure symmetrical around the OY axis, then all of the above mentioned actions (of the basic algorithm) are performed with only one half of it. Only the left or the right part of the geometrical figure must be selected. To get the final hit probability, the number is multiplied by 2 . 
Hit probability of 2D head targets. Calculate the single shot hit probability if the sniper fires to the static head target, which is imited by 1 , 2 types of military shooting targets. The distance between the target and the marksman is $400 \mathrm{~m}$. The median deviations of the shot dispersion are expressed by the following dependence $B_{h}=B_{d}=0.06 \mathrm{~m}\left(B_{h}=B_{y}\right.$; $\left.B_{z}=B_{d}\right)$. The coordinates of the POI represent the midpoint of the target. Estimate the hit probability for the head target of the first and second types. The dimensions of the targets are shown in Fig. 4. The target dimensions are given in meters. Both targets simulate a human head in a protective military helmet. The $O X$ axis is the horizontal distance from the $O Z$ axis to the target direction (line $O C$ ).

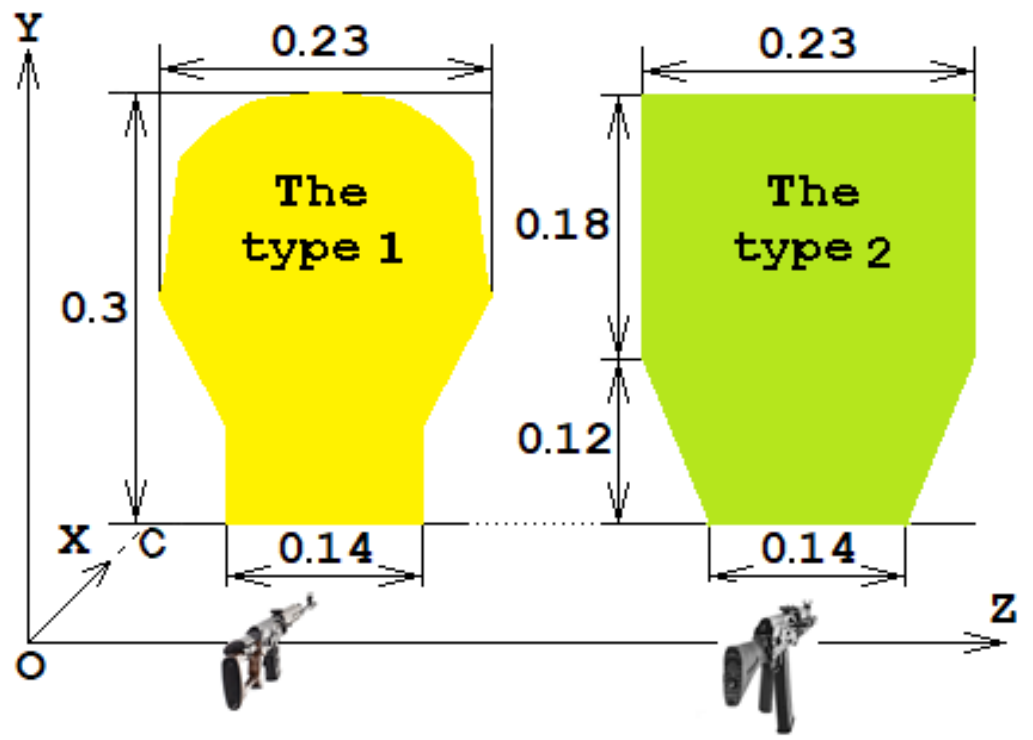

Figure 4 - Two types of $2 D$ head shooting targets in the Cartesian coordinates YOZ

Puc. 4 - Два типа плоских стрелковых головных мишеней в декартовых координатах YOZ

Слика 4 - Два типа 2Д мета у облику главе у Декартовом координатном систему YOZ

The characteristics of the dispersion ellipse (semi-major and semiminor axes) will be determined as a probable error (B) in meters. This dispersion characteristic, along with the standard deviation $(\sigma)$, is used often in the theory of shooting. For normal distribution, the relationship between $\sigma$ and $B$ is

$$
B=0.6745 \sigma \quad \text { or } \quad \sigma=1.4826 B \text {. }
$$


The probable error height is characterized by $B_{h}$ and the probable error deflection $-B_{d}$.

The contour of the targets is indicated using numbers. The points of the rectangle, inside which the target is located, are indicated using letters.

The contour of the head target of type 1 consists of 12 points: 1-2-345-6-7-8-9-10-11-12 (Fig. 5a). The dimensions of the targets (Fig. 5) are given in meters.

Points 6,12 of the type 1 target belong to the axis of symmetry $O^{\prime} Y^{\prime}$ (1-2-3-4-5-6 + 6-7-8-9-10-11-12) (Fig. 5a). Therefore, the calculation will be conducted with the left half of this figure (points 12-1..6). The coordinates of the points for the contour line and the analytic functions of its elements for the head target of type 1 are collected in Table 1. The sign «cross» (Fig. 5a) means the position of the POI.

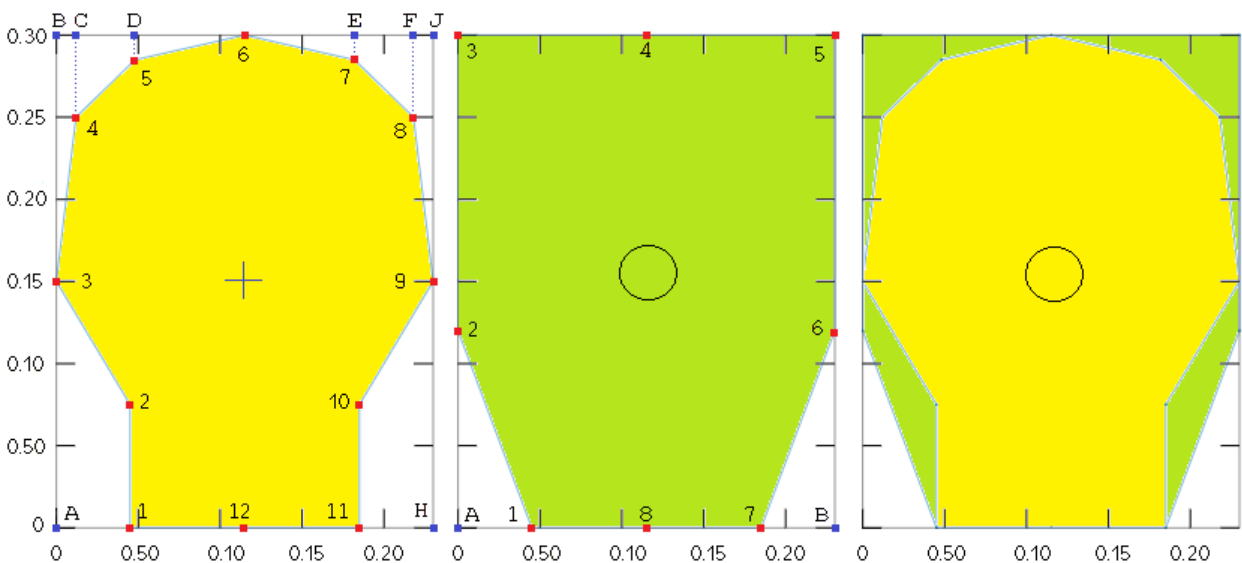

a)

b)

c)

Figure 5 - The contour of the 2D head target type 1 (a), type 2 (b) and their comparison (c)

Рис. 5 - Контур плоской головной мишени типа 1 (a), типа 2 (b) и их сравнение (c) Слика 5 - Контуре 2Д мета у облику главе типа 1 (а), типа 2 (б) и њихово поређење (u)

The contour of the type 2 head target consists of 8 points (Fig. 5b). Points 4, 8 of the type 2 head target belong to the axis of symmetry $O^{\prime} Y$ '. So, the calculation will be conducted with the left half of this figure (points $1-6,12)$. The coordinates of the points for the contour line and the analytic functions of its elements for the type 1 head target are collected in Table 3. 
Table 1 - Coordinates of the points for the contour line for the head target of type 1 Таблица 1 - Координаты точек контура мишени типа 1

Табела 1 - Координате тачака контурне линије мете у облику главе типа 1

\begin{tabular}{|c|c|c|c|c|}
\hline $\begin{array}{c}\text { No. of } \\
\text { points }\end{array}$ & $\mathrm{Z}, \mathrm{m}$ & $\mathrm{Y}, \mathrm{m}$ & $\begin{array}{c}\text { Boundary } \\
\text { points of line }\end{array}$ & $\begin{array}{c}\text { Analytic function } \\
\text { (Equation of a straight line) }\end{array}$ \\
\hline 1 & 0.045 & 0.000 & $1-2$ & $\mathrm{z}(\mathrm{y})=0.045$ \\
\hline 2 & 0.045 & 0.075 & $2-3$ & $\mathrm{y}(\mathrm{z})=-1.6667^{\star} \mathrm{z}+0.15$ \\
\hline 3 & 0.000 & 0.150 & $3-4$ & $\mathrm{y}(\mathrm{z})=8.3333^{\star} \mathrm{z}+0.15$ \\
\hline 4 & 0.012 & 0.250 & $4-5$ & $\mathrm{y}(\mathrm{z})=0.97222^{\star} \mathrm{z}+0.23833$ \\
\hline 5 & 0.048 & 0.285 & $5-6$ & $\mathrm{y}(\mathrm{z})=0.22388^{*} \mathrm{z}+0.27425$ \\
\hline 6 & 0.115 & 0.300 & $6-7$ & $\mathrm{y}(\mathrm{z})=-0.22388^{*} \mathrm{z}+0.32575$ \\
\hline 7 & 0.182 & 0.285 & $7-8$ & $\mathrm{y}(\mathrm{z})=-0.97222^{*} \mathrm{z}+0.46194$ \\
\hline 8 & 0.218 & 0.250 & $8-9$ & $\mathrm{y}(\mathrm{z})=-8.3333^{*} \mathrm{z}+2.06667$ \\
\hline 9 & 0.230 & 0.150 & $9-10$ & $\mathrm{y}(\mathrm{z})=1.6667^{*} \mathrm{z}-0.23333$ \\
\hline 10 & 0.185 & 0.075 & $10-11$ & $\mathrm{z}(\mathrm{y})=0.185$ \\
\hline 11 & 0.185 & 0.000 & $11-12$ & $\mathrm{y}(\mathrm{z})=0$ \\
\hline 12 & 0.115 & 0.000 & $12-1$ & $\mathrm{y}(\mathrm{z})=0$ \\
\hline
\end{tabular}

Table 2 - Coordinates of the points for the contour line for the head target of type 2 Таблица 2 - Координаты точек контура мишени типа 2

Табела 2 - Координате тачака за контурну линију мете у облику главе типа 2

\begin{tabular}{|c|c|c|c|c|}
\hline No. of points & $\mathrm{Z}, \mathrm{m}$ & $\mathrm{Y}, \mathrm{m}$ & $\begin{array}{c}\text { Boundary } \\
\text { points of line } \\
\text { (of curves) }\end{array}$ & $\begin{array}{c}\text { Analytic function } \\
\text { (Equation of a straight line) }\end{array}$ \\
\hline 1 & 0.045 & 0.000 & $1-2$ & $\mathrm{y}(\mathrm{z})=-0.26667^{*} \mathrm{z}+0.012$ \\
\hline 2 & 0.000 & 0.012 & $2-3$ & $\mathrm{z}(\mathrm{y})=0$ \\
\hline 3 & 0.000 & 0.300 & $3-4$ & $\mathrm{y}(\mathrm{z})=0.3$ \\
\hline 4 & 0.115 & 0.300 & $4-5$ & $\mathrm{z}(\mathrm{z})=0.3$ \\
\hline 5 & 0.230 & 0.300 & $5-6$ & $\mathrm{y}$ \\
\hline 6 & 0.230 & 0.012 & $6-7$ & $\mathrm{y}(\mathrm{z})=0.26667^{*} \mathrm{z}-0.04933$ \\
\hline 7 & 0.185 & 0.000 & $7-8$ & $\mathrm{y}(\mathrm{z})=0$ \\
\hline 8 & 0.115 & 0.000 & $8-1$ & 0 \\
\hline
\end{tabular}

A comparison of the forms of the type 1 target and the type 2 target is shown in Fig. 5c.

One sigma dispersion circle $^{3}$ (zone) is shown in Figures $5 \mathrm{~b}$ and $5 \mathrm{c}$.

\footnotetext{
${ }^{3}$ Dispersion area has the form of a circle because $\sigma y=\sigma z$ but in the case of $\sigma y \neq \sigma z$, it would be a dispersion ellipse.
} 
The result of dividing the half of the type 1 target into four sections, the determination of five double integrals and the numerical computations of the double integrals are given in Table 3. The first double integral (region AB-6-12) describes the hit probability into a rectangle inside which there is $50 \%$ of the target contour.

The characteristics of the dispersion and the dispersion center are indicated in Table 3 after «Notes». The unit of measure is the meter.

Table 3 - Characteristics of the base region and sub-regions for the type 1 target Таблица 3 - Характеристики базовой области и подобластей мишени типа 1

Табела 3 - Карактеристике основне области и подобласти за мету типа 1

\begin{tabular}{|c|c|c|c|}
\hline $\begin{array}{l}\text { No. of } \\
\text { regions }\end{array}$ & $\begin{array}{l}\text { Hit } \\
\text { probabilities } \\
\text { for regions }\end{array}$ & $\begin{array}{c}\text { Hit probability as an expression with the } \\
\text { double integral }\end{array}$ & $\begin{array}{l}\text { Numerical } \\
\text { estimation of } \\
\text { hit probability }\end{array}$ \\
\hline $\begin{array}{c}1 . \\
A B-6-12 \\
\end{array}$ & $P_{h i t_{\text {basic }}^{t y p e 1}}$ & $\int_{0}^{0.115} \int_{0}^{0.3} f(z, y) d z d y$ & 0.266 \\
\hline $\begin{array}{c}2 . \\
\text { A-3-2-1 }\end{array}$ & $P_{h i t_{1}^{t y p e 1}}$ & $\int_{0}^{0.045} \int_{0}^{-1.6667 \cdot z+0.15} f(z, y) d z d y$ & 0.027 \\
\hline $\begin{array}{l}3 . \\
3-B C-4\end{array}$ & $P_{h i t_{2}^{t y p e 1}}$ & $\int_{0}^{0.012} \int_{8.333 \cdot z+0.15}^{0.3} f(z, y) d z d y$ & $2.3 e-3$ \\
\hline $\begin{array}{c}4 . \\
4-C D-5\end{array}$ & $P_{h i t_{3}^{t y p e 1}}$ & $\int_{0.012}^{0.048} \int_{0.97222 \cdot z+0.23833}^{0.3} f(z, y) d z d y$ & $1.561 \mathrm{e}-3$ \\
\hline $\begin{array}{c}5 . \\
5-D-6\end{array}$ & $P_{h i t_{4}^{t y p e 1}}$ & $\int_{0.048}^{0.115} \int_{0.22388 \cdot z+0.27425}^{0.3} f(z, y) d z d y$ & $8.684 \mathrm{e}-4$ \\
\hline Notes: & \multicolumn{3}{|c|}{$\begin{array}{l}\mathrm{m}_{\mathrm{y}}=0.115 \mathrm{~m} ; \mathrm{m}_{\mathrm{z}}=0.15 \mathrm{~m} ; \sigma_{\mathrm{y}}=\sigma_{\mathrm{z}}=1.4826 \cdot 0.06=0.089 \mathrm{~m} . \\
\text { The numerical integration was performed due to computer algebra } \\
\text { systems (CAS) Mathcad } 15\end{array}$} \\
\hline
\end{tabular}
formula

The probability of hitting the type 1 target is determined by the

$$
P_{h i t}=2\left\lfloor P_{h i t_{b a s i c}^{t p p e 1}}-\sum_{i=1}^{4} P_{h i t_{i}^{t p p e 1}}\right\rfloor .
$$

Substituting the data from Table 3 into the formula, we obtain the required hit probability.

$$
\begin{gathered}
P_{h t_{\text {type }}}=2 \cdot\left(0.266-\left(0.027+2.3 \cdot 10^{-3}+1.561 \cdot 10^{-3}+8.684 \cdot 10^{-4}\right)\right)=0.468 . \\
P_{h t_{t y p e 1}}=46.8 \% .
\end{gathered}
$$


An estimate of the hit probability for a target of type 2 is carried out in a similar way. The result of dividing the half of the type 2 target into two sections, the determination of two double integrals and the numerical computations of the double integrals are given in Table 4.

Table 4 - Characteristics of the base region and sub-regions for the type 2 target Таблица 4 - Характеристики базовой области и подобластей мишени типа 2

Табела 4 - Карактеристике основне области и подобласти за мету типа 2

\begin{tabular}{|c|c|c|c|}
\hline $\begin{array}{l}\text { No. of } \\
\text { regions }\end{array}$ & \begin{tabular}{|c|} 
Hit \\
probabilities \\
for regions \\
\end{tabular} & $\begin{array}{l}\text { Hit probability as an expression with the } \\
\text { double integral }\end{array}$ & $\begin{array}{c}\text { Numerical } \\
\text { estimation of hit } \\
\text { probability }\end{array}$ \\
\hline $\begin{array}{c}1 . \\
\text { A-3-4-6 } \\
\end{array}$ & $P_{\text {hit }}^{\text {type } 2}$ & $\int_{0}^{0.115} \int_{0}^{0.3} f(z, y) d z d y$ & 0.266 \\
\hline $\begin{array}{c}2 . \\
A-2-1\end{array}$ & $P_{h i t_{1}^{t p p e 2}}$ & $\int_{0}^{0.045} \int_{0}^{-2.6667 \cdot z+0.12} f(z, y) d z d y$ & 0.029 \\
\hline the & \multicolumn{3}{|c|}{$\begin{array}{l}m_{y}=0.115 m ; m_{z}=0.15 m ; \sigma_{y}=\sigma_{z}=1.4826 \cdot 0.06=0.089 \mathrm{~m} . \\
\text { The numerical integration was performed due to CAS Mathcad } 15 .\end{array}$} \\
\hline
\end{tabular}

The characteristics of the dispersion and the dispersion center by firing at targets of both type 1 and 2 are the same.

The hit probability for the type 2 target is determined by the formula:

$$
P_{h i t_{b y p e 2}}=2\left[P_{h i t_{b a s i c}^{t p p e 2}}-P_{h i t_{1}^{t y p e 2}}\right\rfloor=2 \cdot(0.266-0.029)=0.474 \text { or } 47.4 \% \text {. }
$$

The performed calculations have shown that with the identical dispersion characteristics and the identical location of the POI, the hit probability of the target $1(46.8 \%)$ is less than the hit probability of the target $2(47.4 \%)$. This fact is explained by the fact that the target area 2 is larger than the target area 1 . This phenomenon is explained by the fact that the area of the target 2 is larger than the area of the target 1 (see Fig. 5c).

In this situation, the method of calculation gave an adequate result. The second test for the calculation method will relate to its solving despite a known result.

Verification by the comparison with the already existing, previously determined results. In order to verify the method developed in this article, we will perform 3 variants of hit probability estimates. As an example, we use the problem given in (Venttsel', 2006, p.197).

Shooting is carried out at a rectangular target of $9 \times 12$ (meters). The projectile dispersion characteristics are defined as probable errors: in the 
longitudinal direction $B_{y}=10 \mathrm{~m}$, in the lateral direction $B_{z}=5 \mathrm{~m}$. The point of aiming (POA) is the center of the considered rectangular target. Thus the POA has the coordinates $(0 ; 0)$. In view of the presence of shooting errors, the mean point of impact is displaced relative to the POA. The coordinates of the POI are $(0 ;-4)$. Find the single shot hit probability.

The points $(-4.5 ;-6),(-4.5 ; 6),(4.5 ; 6),(-4.5 ;-6)$ are the four vertices of a rectangular target. The dispersion characteristics are expressed in the form of standard deviations (SD). The SD in the longitudinal direction is $\sigma_{y}=1.4826 \cdot B_{y}=14.826 \mathrm{~m}$. The SD in the lateral direction is $\sigma_{z}=$ $1.4826 \cdot B_{z}=7.413 \mathrm{~m}$. Since the coordinates of the center of dispersion (namely the POI) are known, then $m_{y}=-4$, and $m_{z}=0$.

Variant of calculation 1 uses a formula for the estimation of hit probability for the rectangle (Venttsel', 2006, p.197).

Let us write down the target hit probability formula into a rectangle $(R-$ area), the dispersion axes of which are parallel to the sides of the rectangle (Germershausen, 1977, p.193):

$$
\begin{gathered}
P_{h i t}[(Z, Y) \subset R]=\left[F\left(\frac{b-m_{z}}{\sigma_{z}}\right)-F\left(\frac{a-m_{z}}{\sigma_{z}}\right)\right] . \\
\cdot\left[F\left(\frac{d-m_{y}}{\sigma_{y}}\right)-F\left(\frac{c-m_{y}}{\sigma_{y}}\right)\right] \cdot \\
P_{h i t}[(Z, Y) \subset R]=\left[F\left(\frac{b-m_{z}}{\sigma_{z}}\right)-F\left(\frac{a-m_{z}}{\sigma_{z}}\right)\right] \cdot\left[F\left(\frac{d-m_{y}}{\sigma_{y}}\right)-F\left(\frac{c-m_{y}}{\sigma_{y}}\right)\right] .
\end{gathered}
$$

where $F(x)$ - the cumulative distribution function (CDF) of the standard normal distribution (Germershausen, 1977, p.193):

$$
F(x)=\frac{1}{\sqrt{2 \pi}} \int_{-\infty}^{x} \exp \left(-\frac{1}{2} t^{2}\right) d t .
$$

In formula 3: $m_{y}, m_{z}$ - the coordinates of the center of dispersion; $\sigma_{y}$, $\sigma_{z}$ - the standard deviation; $a, b, c, d-$ the borders of the targetrectangle sides, herewith $c \leq y \leq d, a \leq z \leq b$.

Taking into account the previously defined values, formula 3 is transformed into the form: 


$$
\begin{gathered}
P_{h i t}[(Z, Y) \subset R]=\left[F\left(\frac{b}{\sigma_{z}}\right)-F\left(\frac{a}{\sigma_{z}}\right)\right] \cdot\left[F\left(\frac{d-m_{y}}{\sigma_{y}}\right)-F\left(\frac{c-m_{y}}{\sigma_{y}}\right)\right]= \\
=\left[F\left(\frac{4.5}{7.413}\right)-F\left(\frac{-4.5}{7.413}\right)\right] \cdot\left[F\left(\frac{6-(-4)}{14.826}\right)-F\left(\frac{-6-(-4)}{14.826}\right)\right]= \\
=\left[F\left(\frac{4.5}{7.413}\right)-F\left(\frac{-4.5}{7.413}\right)\right] \cdot\left[F\left(\frac{10}{14.826}\right)-F\left(\frac{-2}{14.826}\right)\right]= \\
=[F(0.60704)-F(-0.60704)] \cdot[F(0.67449)-F(-0.1349)]= \\
\quad=[0.728088-0.271912] \cdot[0.75-0.446345]=0.13852 .
\end{gathered}
$$

So $P_{\text {hit }}$ by shooting with the above mentioned projectile dispersion parameters is $13.85 \%$.

Variant of calculation 2 is based on the mathematical function "erf»" (Khaikov \& Popovnin, 2018). The error function is defined (Zwillinger \& Kokoska, 2000, p.516) by

$$
\operatorname{erf}(x)=\frac{1}{\sqrt{\pi}} \int_{0}^{x} \exp \left(-t^{2}\right) d t
$$

There is a following relation between the cumulative distribution function $F(x)$ of the standard normal distribution and the function «erf» (Zwillinger \& Kokoska, 2000, p.517):

$$
F(x)=\frac{1}{2}\left[1+\operatorname{erf}\left(\frac{1}{\sqrt{2}} x\right)\right]
$$

Therefore, formula 3 is transformed into the form (Khaikov \& Popovnin, 2018)

$$
P_{h i t}=\frac{1}{4}\left[\operatorname{erf}\left(\frac{b-m_{z}}{\sqrt{2} \sigma_{z}}\right)-\operatorname{erf}\left(\frac{a-m_{z}}{\sqrt{2} \sigma_{z}}\right)\right] \cdot\left[\operatorname{erf}\left(\frac{d-m_{y}}{\sqrt{2} \sigma_{y}}\right)-\operatorname{erf}\left(\frac{c-m_{y}}{\sqrt{2} \sigma_{y}}\right)\right] .
$$

Taking into account the data given in the task, we obtain

$$
P_{h i t}=\frac{1}{4}\left[\operatorname{erf}\left(\frac{b}{\sqrt{2} \sigma_{z}}\right)-\operatorname{erf}\left(\frac{a}{\sqrt{2} \sigma_{z}}\right)\right] \cdot\left[\operatorname{erf}\left(\frac{d-m_{y}}{\sqrt{2} \sigma_{y}}\right)-\operatorname{erf}\left(\frac{c-m_{y}}{\sqrt{2} \sigma_{y}}\right)\right] \text {. }
$$


Substitute the initial data in the formula and perform the estimation

$$
\begin{gathered}
P_{h i t}=\frac{1}{4}\left[\operatorname{erf}\left(\frac{4.5}{\sqrt{2} \cdot 7.413}\right)-\operatorname{erf}\left(\frac{-4.5}{\sqrt{2} \cdot 7.413}\right)\right] . \\
\cdot\left[\operatorname{erf}\left(\frac{6-(-4)}{\sqrt{2} \cdot 14.826}\right)-\operatorname{erf}\left(\frac{-6-(-4)}{\sqrt{2} \cdot 14.826}\right)\right]=0.13852 .
\end{gathered}
$$

The results of the calculations for versions 1 and 2 are the same.

Variant of calculation 3 uses a numerical integration of the double integral.

The purpose of this comparison is to show the universality of the developed method for calculating the hit probability for targets of rectangular shapes as well as for targets with arbitrary contours.

For a shooting target with a rectangular shape, we write the double integral

$$
\begin{gathered}
P_{h i t}=\frac{1}{2 \pi \sigma_{z} \sigma_{y}} \int_{a}^{b} \int_{\varphi_{1}(z)}^{\varphi_{2}(z)} f^{*}(z, y) d z d y=\frac{1}{2 \pi \sigma_{z} \sigma_{y}} \int_{-4.5}^{4.5} d z \int_{-6}^{6} f^{*}(z, y) d y, \\
f^{*}(z, y)=\exp \left(-\left[\frac{(z-0)^{2}}{2 \sigma_{z}^{2}}+\frac{(y-(-4))^{2}}{2 \sigma_{y}^{2}}\right]\right) .
\end{gathered}
$$

For numerical integration, we use the possibilities of the computer software Mathcad 15. The Mathcad code is below. All variables have been described previously.

$$
\begin{aligned}
& \mathrm{a}:=-4.5 \quad \mathrm{~b}:=4.5 \quad \mathrm{c}:=-6 \quad \mathrm{~d}:=6 \quad \mathrm{TOL}:=0.0001^{4} \\
& m y:=-4 \quad m z:=0 \quad \sigma y:=14.826 \quad \sigma z:=7.413 \\
& \frac{1}{2 \pi} \frac{1}{\sigma z} \frac{1}{\sigma y} \int_{a}^{b} \int_{c}^{d}\left[\exp \left[-\left[\frac{(z-m z)^{2}}{2 \sigma z^{2}}+\frac{(y-m y)^{2}}{2 \sigma y^{2}}\right]\right]\right] d y d z=0.139 \text {. }
\end{aligned}
$$

As in the first two cases, we obtained a single shot hit probability, which is 0.139 or $13.9 \%$.

\footnotetext{
${ }^{4}$ The accuracy of the calculation in the Mathcad software is determined by the value of the system variable TOL, which is equal to 0.001 by default.
} 
The coordinates $m_{y}, m_{z}$ of the $\mathrm{POI}$ for rifles and pistols can be obtained by calculating the "average trajectory» (Khaikov, 2018). For example, for a sniper rifle SVD-63 (7.62 mm Dragunov sniper rifle) the results of the work (Khaikov, 2017) can be used.

\section{Conclusion}

A geometric interpretation of single shot hit probability of a target is the volume under a surface $f(y, z)$, which is described by a bivariate normal distribution and limited from below the YOZ plane with a target contour ( $T$-region).

The hit probability $\left(P_{\text {hit }}\right)$ is preferably to be estimated by the numerical integration of the double integral. The integrand of the double integral is the two-dimensional normal distribution of a system of random variables $Y$ and $Z$. The dispersion characteristics and the coordinates of the dispersion center are known in advance. The limits of two integrals are described by the analytic functions characterizing the geometric shape of the target boundaries.

The developed schema for the numerical solution of the $P_{\text {hit }}$ makes it possible to calculate the probability for targets with arbitrary geometric shapes.

The estimation of the hit probability for the type 1 and type 2 head targets, if the coordinates of the POI represent the target midpoint and $B_{y}$ $=B_{z}=0.06 \mathrm{~m}$, is as follows: it is $46.8 \%$ for the type 1 target and $47.4 \%$ for the type 2 target. The $P_{\text {hit }}$ estimations are produced using numerical integration in the computer application Mathcad.

The developed method was compared with the already existing works and was verified by hit probability calculations for two types of head shooting targets. The result of the comparison is a difference in the third digit after the decimal point.

\section{References}

Abezgauz, G.G., Tron', A.P., Kopenkin, Yu.N. \& Korovina, I.A. 1970. Spravochnik po veroyatnostnym raschetam. Moscow: Voyennoye izdatel'stvo ministerstva oborony SSSR (in Russian). (In the original: Абезгауз, Г.Г., Тронь А.П., Копенкин Ю.Н., Коровина И.А. 1970. Справочник по вероятностным расчётам. Москва: Военное издательство министерства обороны СССР).

Germershausen, R. (ed.) 1977. Rheinmetall Waffentechnisches Taschenbuch. Düsseldorf: Rheinmetall GmbH (in German). 
Khaikov, V.L. 2017. Ballistical mathematical model of the Dragunov sniper rifle based on a ballistic coefficients estimation using tabular firing table data. Military Enginery, Counter-terrorism technical devices, 16(11-12/113-114), pp.16-23 (in Russian).

Khaikov, V.L. 2018. Improvement of longitudinal motion description for axisymmetric body due to the functional ballistical matrix. Electronic Information Systems, 2(17), pp.101-115 (in Russian).

Khaikov, V.L., \& Popovnin, Y.M. 2018. Using mathematical software Microsoft Excel, Matlab/Octave for hit-probability assessment in standard shooting-targets. Military Enginery, Counter-terrorism technical devices, 16(34/117-118), pp.96-103 (in Russian).

Piskunov, N.S. 1985. Differentsial'noye i integral'noye ischisleniya. Tom 2. Moscow: Nauka (in Russian). (In the original: Пискунов Н.C. 1985. Дифрференциальное и интегральное исчисления. Том 2. Москва: Наука).

Rodney, S. 2012. RPG encounter modeling. SURVIAC Bulletin, 27(1), pp.1-5.

Svateev, V.A. 2014. Tochnyy sposob raschota veroyatnosti popadaniya v figurnuyu tsel'. Bulletin of the Academy of Military Sciences, 49(4), pp.61-66 (in Russian). (In the original: Сватеев B.A. 2014. Точный способ расчёта вероятности попадания в фигурную цель. Вестник Академии военных наук. 2014. T. 49, № 4. C. 61-66.)

Venttsel', Ye.S. 2006. Teoriya veroyatnostey. Moscow: Vysshaya shkola (in Russian). (In the original: Вентцель Е.С. 2006. Теория вероятностей. Москва: Высшая школа).

Vodorezov, Yu.G. 2017. Teoriya i praktika strel'by iz nareznogo dlinnostvol'nogo strelkovogo oruzhiya. Chast' 1. Moscow: Moskovskiy Gosudarstvennyy Tekhnicheskiy Universitet (in Russian). (In the original: Водорезов, Ю.Г. 2017. Теория и практика стрельбы из нарезного длинноствольного стрелкового оружия. Часть 1. Москва: Московский Государственный Технический Университет).

Zwillinger, D., \& Kokoska, S. 2000. Standard Probability and Statistics tables and formulae. London - New York: Chapman \& Hall CRC.

\section{ОЦЕНКА ВЕРОЯТНОСТИ ПОПАДАНИЯ В МИШЕНЬ ОДИНОЧНЫМ ВЫСТРЕЛОМ КАК РЕЗУЛЬТАТ ЧИСЛЕННОГО ИНТЕГРИРОВАНИЯ МАТЕМАТИЧЕСКОГО ВЫРАЖЕНИЯ С ДВОЙНЫМ ИНТЕГРАЛЛОМ В ПРОГРАММЕ МАТНСАD \\ Вадим Л. Хайков, \\ независимый исследователь, г. Краснодар, Российская Федерация}

ОБЛАСТЬ: прикладная математика

ВИД СТАТЬИ: оригинальная научная статья

ЯЗЫК СТАТЬИ: английский 
Резюме:

Вероятность попадания одиночным выстрелом в цель предложено оценивать формулой, основу которой составляет двойной интеграл. Подынтегральная фрункция описывает двумерное рассеивание системы случайных величин Y, Z с заранее заданными параметрами координат рассеивания и среднеквадратических отклонений по направлениям $Y, Z$. Пределы интегрирования описывают геометрическую фрорму стрелковой мишени и являются аналитическими фрункциями границ мишени. В статье предложен алгоритм решения задачи оценки вероятности попадания, который позволяет вычислять вероятности попадания в мишени произвольной геометрической формы. На первом шаге алгоритма производится разбиение цели на $N$ геометрических подобластей. Далее для каждой из подобластей записывается двойной интеграл и с помощью численного интегрирования получают его количественную оценку. Далее результаты вычислений (вероятности попаданий в подобласти) складываются (вычитаются). C целью численного интегрирования двойного интеграла использована среда математических вычислений Mathcad. Для иллюстрации работоспособности предложенного метода приведены расчёты определения вероятности попадания в головную цель двух видов.

Ключевые слова: вероятность попадания, численное решение, стрелковая мишень, двойной интеграл, рассеивание пуль, Mathcad.

ПРОЦЕНА ВЕРОВАТНОЋЕ ПОГАЂАЊА ЦИЉА ЈЕДНИМ ХИЦЕМ КАО РЕЗУЛТАТ НУМЕРИЧКОГ РЕШАВАҢА ДВОСТРУКИХ ИНТЕГРАЛА ПОМОКУ МАТНСАD-а

Вадим Л. Хајков

независни истраживач, Краснодар, Руска Федерација

ОБЛАСТ: примењена математика

ВРСТА ЧЛАНКА: оригинални научни чланак

ЈЕЗИК ЧЛАНКА: енглескИ

Сажетак:

Вероватноћа поготка циља једним хицем представља се геометријски запремином испод површине $f(y, z)$ која је описана биваријантном нормалном расподелом ограниченом контуром циља (област T) испод равни YOZ. Предлаже се да се вероватноћа поготка $\left(P_{h i t}\right)$ процењује методом заснованим на нумеричкој интеграцији двоструког интеграла. Интегранд двоструког интеграла је дводимензионална нормална расподела система случајних варијабли $Y$ u Z. Карактеристике растурања и 
координате центра растурања познате су унапред. Границе два интеграла описане су аналитичким фрункцијама које карактеришу геометријски облик контура циља. Изабрани циљ се прво дели на $N$ геометријских подобласти, а затим се за границе сваке од њих одређују аналитичке формуле и пише двоструки интеграл. Вероватноћа поготка процењује се нумеричком интеграцијом у Mathcad-y. Резултати израчунавања свих вероватноћа поготка (свих подобласти) сабирају се или одузимају, зависно од геометријских односа између подобласти. Шема нумеричког израчунавања вероватноће поготка омогућава израчунавање вероватноће за мете произвољног геометријског облика, а не само за правоугаоне мете. Да би се илустровала операбилност предложеног метода, процењена је вероватноћа поготка за две врсте мета у облику главе. Предложени метод упоређен је с резултатима већ постојећих радова.

Кључне речи: вероватноћа поготка, нумеричко решавање, мета, двоструки интеграли, растурање погодака, Mathcad.

Paper received on / Дата получения работы / Датум пријема чланка: 14.05.2018. Manuscript corrections submitted on / Дата получения исправленной версии работы / Датум достављања исправки рукописа: 22.06.2018.

Paper accepted for publishing on / Дата окончательного согласования работы / Датум коначног прихватања чланка за објављивање: 24.06.2018.

(C) 2018 The Author. Published by Vojnotehnički glasnik / Military Technical Courier (www.vtg.mod.gov.rs, втг.мо.упр.срб). This article is an open access article distributed under the terms and conditions of the Creative Commons Attribution license (http://creativecommons.org/licenses/by/3.0/rs/).

(c) 2018 Автор. Опубликовано в «Военно-технический вестник / Vojnotehnički glasnik / Military Technical Courier» (www.vtg.mod.gov.rs, втг.мо.упр.срб). Данная статья в открытом доступе и распространяется в соответствии с лицензией «Creative Commons» (http://creativecommons.org/licenses/by/3.0/rs/).

(C) 2018 Аутор. Објавио Војнотехнички гласник / Vojnotehnički glasnik / Military Technical Courier (www.vtg.mod.gov.rs, втг.мо.упр.срб). Ово је чланак отвореног приступа и дистрибуира се у складу са Creative Commons лиценцом (http://creativecommons.org/licenses/by/3.0/rs/).

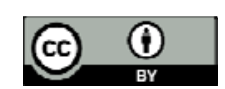

